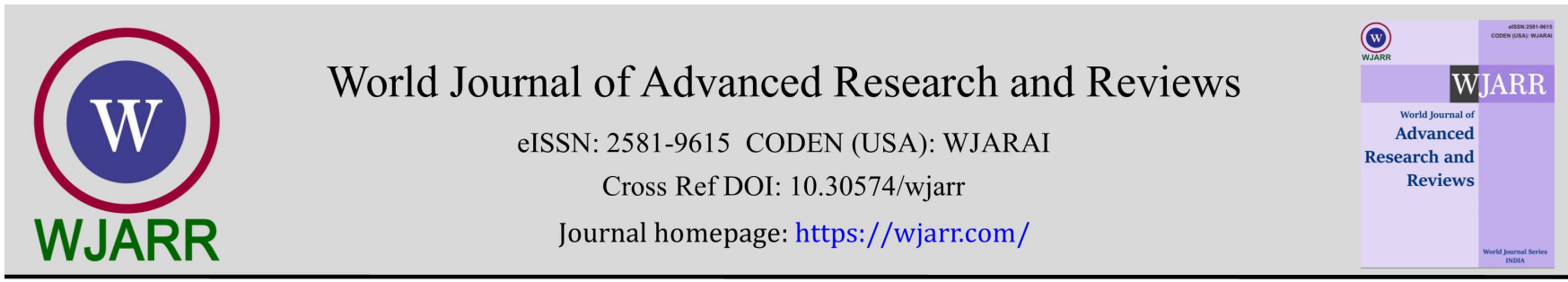

(REVIEW ARTICLE)

\title{
Review of the local tissue reaction to metallic spinal implant debris: Ions and nanoparticles
}

\author{
Magdalena Richter ${ }^{1}$ and Henryk Matusiewicz 2,* \\ ${ }^{1}$ Department of Orthopedics and Traumatology, Poznan University of Medical Sciences, Poznań, Poland. \\ 2 Faculty of Chemical Technology, Poznan University of Technology, Poznań, Poland.
}

World Journal of Advanced Research and Reviews, 2021, 09(03), 167-187

Publication history: Received on 02 February 2021; revised on 04 March 2021; accepted on 06 March 2021

Article DOI: https://doi.org/10.30574/wjarr.2021.9.3.0085

\begin{abstract}
Biologic reactivity to implant debris is the primary determinant of long-term clinical performance. The metallic implants placed in human bodies can exhibit electrochemical or mechanical corrosion that yields in the liberation of metallic products. Such implants-derived metal wear products can be present in the form of metal ions and particulate metal debris with still unknown effects on human health. In situ generation of metallic wear particles, corrosion products and in vivo trace metal ions release from metal and metallic alloys implanted into the body in spine surgery is becoming a major cause for concern regarding the health and safety of patients. In vivo clinical studies addressing the adverse local tissue reaction effects of metallic wear products on surrounding soft tissues and bodily fluids are less numerous. Although numerous studies have focused on the clinical significance of corrosion and wear of hip and knee replacements, research involving spine instrumentation is not well documented. This review explores how migration of metallic wear nanoparticles and trace metal ions in the area of metallic spinal implants influences the surrounding tissues and bodily fluids, and what the clinical consequences of this process may be.
\end{abstract}

Keywords: Spine arthroplasty implants; Adverse local tissue reactions; Metallic particles; In vivo metal ion release; Biological fluids and tissues; Analytical methodology

\section{Introduction}

"An orthopedic implant is a device surgically placed into the body designed to restore function by replacing or reinforcing a damaged structure" [1]. In orthopedic spine surgery, implants are used to treat deformity, mechanical back pain, stenosis, spondylolisthesis, fractures, and tumors. The varied requirements of these implants are diverse, to treat multiple pathologies, in individuals across the lifespan.

The number of orthopedic spine surgeries is on the rise. An epidemiological study conducted by Rajaee observed a $137 \%$ increase in spinal fusion discharge in the USA between the years of 1998 to 2008, a much higher rate than any other orthopedic procedure [2]. However, research in retrieval analysis of spine instrumentation is surprisingly underdeveloped compared to the research of hip or knee retrievals [3]. More patients are undergoing primary spine surgery which could later lead to revision surgeries. Revision surgeries are necessary for patients that experience degenerative disc disease, pseudoarthrosis, mechanical hardware failure, pain, and adjacent segment disease. These complications are often summarized as implant failure. One possible cause of implant failure could be "metallosis" (aseptic black staining) [4]. The majority of studies in this field have focused on total hip and knee replacements [5] with very little information published regarding spinal implants and surgery. Hypotheses generated from the arthroplasty studies including remain inconclusive when applied in spine as the devices and the tissues are not similar. At this point a literature search has uncovered only a very few reported spinal metallosis cases [6-11]. Goldenberg et al.

\footnotetext{
*Corresponding author: Henryk Matusiewicz; E-mail: Henryk.Matusiewicz@put.poznan.pl

Faculty of Chemical Technology, Poznan University of Technology, Poznań, Poland.
} 
[6] found only three relevant articles regarding spinal metallosis (excluding all arthroplasty related studies). The patients included in such case reports displayed neurological symptoms after their initial surgery, leading to a revision procedure to relieve symptoms. Takahashi et al. [7] reported on two cases of intraspinal metallosis in symptomatic patients with spinal instrumentation. They found stained, granulated tissue masses, described as metallosis that had formed in the spinal canal adjacent to the instrumentation leading to neurologic symptoms. A case study by Tezer et al. [8] identified an intraspinal metallosis due to crevice corrosion on stainless steel spinal instrumentation leading to neurological symptoms. After removal of the instrumentation, the patient had complete symptom resolution at the three month checkup appointment. Ayers et al. [9] discussed metallosis in patients who received spinal implants and described their experience with three patients who underwent revision surgery. Signs of fretting, corrosion, galling and corrosion fatigue were found on the retrieved implants. Richman et al. [10] reported on one case of metallosis, four years after a pediatric posterior spinal fusion. Serum chromium levels declined from a high of $4.5 \mu \mathrm{g}$ L- 1 operatively to $0.8 \mu \mathrm{g} \mathrm{L}-1$ at final follow-up but still elevated above the normal reference range (0.2-0.6 $\mu \mathrm{g} \mathrm{L-1)}$. In another report, Teoh et al. [11] presented a case series of five patients who had revision surgery following magnetic controlled growing rods (MGCR) for early onset scoliosis. Metallosis was found during revision in four out of five patients; a significant amount of metal debris was found when the actuators were cut open. These six case studies identify an existing issue and provide evidence for metallosis in spine, but do little to determine mechanisms.

Metallosis can occur in any spinal implant and is found during the revision surgery incidentally. This occurs because of the inconsistency of patient symptoms and the difficulty identifying this phenomenon through imaging techniques. The lack of clinical relevance could explain why this phenomenon is often used to describe the appearance of the tissue instead of a cause for implant failure leading to revision surgery.

This review focuses on the current knowledge of the adverse local tissue reactions to metal particle debris and metal ions released from spine arthroplasty implants in vivo. Specifically, this article explores how migration of metallic wear particles and trace metal ions in the area of a metallic spinal implants influences the surrounding tissues and bodily fluids, and to evaluate the impact of metal ions and particles on clinical outcomes. The systemic effects of elevated metal ions were not evaluated in any of the included studies, and as such were not commented on this review.

\section{Metallic spinal implants}

The use of metals as spine implant materials has become common practice in the field of orthopedics [12]. A wide variety of conditions are treated with metallic spinal implants, and designers have used an assortment of materials to meet the unique mechanical demands of each application, which support the functions of the human body, in particular the skeletal system. The majority of different metallic spinal implants used today, whether rods, hooks, cages, crosslink connectors, anterior plates, pins, inter-body spacers, pedicle screws, are made of stainless steel, cobalt-chrome alloy, titanium, Nitinol (a nickel and titanium alloy), or tantalum.

Surgical medical grade stainless steel 316L, with varying degrees of carbon, chromium, molybdenum, and nickel, is known for its high strength and good ductility, but can be difficult to integrate with bone or soft tissue having poor wear resistance compared to other metallic implants. The addition of molybdenum and lower carbon content of the alloy provides superior corrosion resistance. As a result, the only biocompatible stainless steel is commonly used in fracture fixation devices and/or temporary implants intended to be removed at a later time.

Metallic spinal implant biomaterials: cobalt-chromium alloys (i.e. Co-Cr, Co-Cr-Mo, Co-Cr-W-Ni), titanium Ti-6Al-4V (titanium-aluminum-vanadium) and titanium-based alloys: Ti-Mo (titanium-molybdenum) and Ti-Cr (titaniumchromium), and Nitinol alloy are the most commonly utilized metallic biomaterials used in various spinal implants [13]. Co-based alloys are used more widely in longer-term permanent implants. It is known to have high biocompatibility and good mechanical properties with high wear resistance. Co-Cr-Mo alloys are categorized as bio-tolerant while titanium and its alloys are categorized as bio-inert. Therefore, titanium and its alloys (alloy with aluminum and vanadium) are considered the most biocompatible and popular of all metallic biomaterials due to many fascinating properties, such as superior mechanical properties, strong corrosion resistance, and excellent biocompatibility. Titanium alloys are further categorized according to their phase constitution as $\alpha-,(\alpha+\beta)-$, and $\beta$-type titanium alloys. $ß$-Ti alloys promise to face challenges because they have non-toxic elements and superior corrosion resistance. However, the application of Ti alloys for implant materials is impeded by their poor mechanical strength. Nitinol began to be used in biomedical applications because it demonstrated optimal mechanical characteristics and biocompatibility while also exhibiting a remarkable ability dubbed as the "shape memory effect". It has excellent fatigue resistance, super elasticity, good corrosion resistance, and high damping effect. Tantalum is a metal with notable properties such as high ductility, biologic inertness, resistance to corrosion, a high level of biocompatibility, and ability to incorporate into a 
bone lattice. The downside to tantalum is that it is a rare metal with a high cost, and thus the rod end product is expensive.

Each of these metals and alloys has its own particular strength, rigidity, ductility properties and deficiencies. Their high resistance to corrosion has made them particularly suitable for use in the manufacture of spinal implants. However, prolonged contact of the body tissues with an implant causes a number of unwanted effects, which result in structural changes in the implant itself, reducing the lifetime and local and systemic toxicity.

\section{In vivo corrosion of metallic spinal implants}

All prosthetic implants are subject to some degree of wear and corrosion in the body. Wear is a mechanical process resulting from changes in load distribution and micro-motion, while corrosion is an electrochemical process of metal degradation. Certain types of corrosion, such as fretting, occur when chemical and mechanical factors, including crevice and abrasive wear, act on the implant. Both wear and corrosion result in debris (particles and ions) release from the implants into the surrounding tissues and subsequently into the human circulation, and can manifest with local and systemic reactions which, over time, may demand revision of components.

Corrosion affects spinal instrumentation and may cause local problems such as failure of the implant and/or worse clinical outcomes. Although numerous studies have focused on the clinical significance of corrosion and wear of hip and knee replacements [5], research involving spine instrumentation is not well documented, and studies of metal ion levels in patients with spinal implants are less numerous.

Several case reports have been published on revision of spine components where the reason for revisions was strongly linked with corrosion and wear of the implants [14-23]. Medical complications included unexplained pain, neurological effects, implant loosening, implant failure, swelling and metal staining of the skin.

A pediatric patient with scoliosis was revised twice for persistent pain six and 12 months post-operatively [14]. The first revision was after radiological diagnosis of implant failure, while the second revision was performed to remove soft tissue mass. Histological analysis of tissue taken during revision revealed metal debris and presence of macrophages. In this case, pin was associated with unstable fusion and implant loosening. Gaine and co-workers [15] reported six cases of later operative pain associated with debris release from stainless steel implants. A retrieval study by Kirkpatrick et al. [16] identified three common modes of corrosion and wear that appear to happen simultaneously in vivo; fretting wear, crevice and galvanic corrosion. In a retrieval study conducted by Villarraga et al. [17] and Panagiotopoulou et al. [18] wear and corrosion were the most common types of damage seen on retrieved spinal hardware and they concluded that revision spine constructs contribute to this type of damage because of the additional segments and mobile pieces added.

Corrosion is not a recently described problem. In fact, Aulisa et al. [19] published, in 1982, a case of corrosion in Harrington instrumentation. Modern spinal instrumentations also suffer corrosion. Akazawa et al. [20] report macroscopic evidence of corrosion in $66.2 \%$ of rod junctions after long-term implantation. Spinal rods made of stainless steel from 11 patients were revised and retrieval analysis was performed. Corrosion and fretting were present at the rod-screw junctions in all constructs, but were more evident on implants with longer time of implantation. The authors suggested that that corrosion can be more rapid in cases where spinal fusion is not achieved compared with fusion cases. Vieweg et al. [21] found corrosion on pedicle screws and telescopic rods after a mean length of implantation of 10 months.

There have been only a few retrospective reports of abnormally elevated levels of nickel and chromium in serum of patients with stainless steel posterior spinal instrumentation [22,23]. Kim et al. [22] studied serum levels of nickel and chromium after posterior spinal arthrodesis with implants made of stainless steel, over long time frames (mean followup of 4 years), without any evidence of corrosion. They observed that these levels rose after surgery and remained above normal levels 4 years after the surgical procedure. While chromium levels diminished rapidly with time, after about 2 years, to the normal range, nickel concentrations above the normal levels were still found in some patients after ( 1.5-2 $\mu \mathrm{g}$ L-1). Nickel and chromium levels in both serum and urine have also been assessed in patients implanted with stainless steel spinal implants with and without evidence of macroscopic corrosion 13-15 years after implantation [23]. Even in the absence of macroscopic corrosion, elevated levels of both elements were observed after more than a decade following surgery. When macroscopic corrosion was evident noting the correlation between significantly higher metal ion levels and radiological signs of device corrosion, nickel was found well outside the limits of the normal range; the reported chromium levels were similarly quite high. 
These case reports conclude that corrosion and wear are independent of materials used in spine instrumentation. Reactions to metal debris can vary from late operative pain to neurological complications, while spine metalloma seems to be the common denominator.

\section{In situ degradation of metallic spinal implants}

Mechanisms involved in the degradation of implants are complex, as is evident from the range of clinical responses with some patients having no complications and others requiring revision of the implant. If the implant is placed in the harsh for metals, biological physiologic environment of the human body and interaction in place of contact of implant - soft tissue - bodily fluids often occurs. The degradation products of any metallic spinal implants (i.e. plates, screws, pins, or nails), and temporary implant applications such as bone plates, screws and prosthetic components in orthopedic spinal implants are primarily generated by metal wear processes and corrosion (either electrochemically or mechanically), or by a combination of the two, of the metal alloy [24]. Spinal implants prostheses generate metallic wear particles and corrosion debris, nanometer- to sub-micrometer metal particles, metal ions and metallo-protein complexes [25]. The toxicological effects of nanoscale metallic or metal oxide particles have been studied, both in vivo and in vitro, and in most cases, these toxicological effects have demonstrated a strong dependence on the particle size and on other surface properties.

This section is focused on releasing of metal nanoparticles and elevated trace metal ions, from the implant surfaces, to the human body (bodily fluids and tissues) since metals have been focused to bear intense wear/corrosion and cause adverse local tissue reactions (ALTRs).

\subsection{Metallic wear particles}

Metal implants induce the transfer of some metallic wear particles from any orthopedic and spinal implant to surrounding soft tissues [26]. The use of metal instrumentation, particularly titanium, for spinal fusion has introduced the possibility of generating microscopic metal particles, detected by microradiography that may be deposited in the paraspinal soft tissues surrounding the spine [21].

In the presence of a pseudarthrosis, corrosion and deposition of metallic particulate matter in the surrounding tissue have been seen [27]. Elevated tissue Ti concentration of up to 50 times the normal levels was observed in tissues surrounding spinal implants. Metal particles (wear debris) were generated by the use of titanium spinal instrumentation (pedicle screws) in patients with a pseudarthrosis. This particle remains in the soft tissues: tissue concentrations of titanium were highest in patients with a pseudarthrosis (30.36 $\mu \mathrm{g}$ g-1 of dry tissue); patients with a solid fusion had low concentrations of titanium $(0.586 \mu \mathrm{g}$ g- 1 of dry tissue). Standard light microscopy, transmission electron microscopy and X-ray dispersive microanalyses of particles were performed to confirm the presence of elemental Ti in soft tissues.

A study of Ti level in tissues surrounding a spinal implant by Lukina et al. [28] found a 1,800 fold increase in Ti tissue concentrations in pediatric patients with implanted growth guidance sliding commercially pure titanium (cpTi) constructs (titanium alloy Ti-6Al-4V), when compared to patients with no metal implants. This value is much higher than any previously reported findings.

Ayers et al. [9] discussed metallosis in patients who received spinal implants and described their experience with three patients who underwent revision surgery. Signs of fretting, corrosion, galling and corrosion fatigue were found on the retrieved implants. Concentration of $\mathrm{Al}, \mathrm{Co}, \mathrm{Cr}, \mathrm{Mo}$, and $\mathrm{V}$ in removed muscle tissue were significantly elevated compared to published reference values for muscle.

To establish the types of particulate metallic debris around human stainless steel spinal implants the tissue around 14 spinal implants were analyzed by light microscopy, transmission electron microscopy and scanning electron microscopy along with electron dispersion radiograph analysis [29]. Two types of metallic debris were identified. The rusty appearing particles contained mostly iron, whereas the black appearing particles were rich in chromium.

Krischak et al. [30] found that stainless steel is more likely to corrode with a markedly higher amount of potentially toxic metallic particles release in the soft tissues compared with cpTi implants. Grades of corrosion were significantly increased in stainless steel implants compared with implants made of cpTi.

Golasik et al. [31] reported the determination of low titanium concentrations in 9 soft tissue samples from 3 pediatric patients obtained on the day of the surgery for the placement of a growing spinal implant. 
The quantitation of metallic wear particles in situ isolated from human soft tissue adjacent to the implanted metallic spinal devices is presented in Table 1.

\subsection{Concentrations of trace metal ions in human bodily fluids}

Metal spine implants generate metallic wear nanoparticles, corrosion products and trace metal ions. Moreover, wear particles may undergo a corrosion process contributing to enhance the metal ion level. Metal released from implants may remain local to the joint or enter the local blood circulation and accumulate in several tissues, including the soft tissue surrounding metallic spinal implants. It is generally accepted that elevated metal ion levels generated by metallic prostheses are toxic to the human body, with potential local consequences. Most in vivo studies that have been published in the literature are related to the effects induced by chromium, nickel, and titanium in human biological specimens. Other known potential toxic metal ions released by metallic spinal implants are vanadium, aluminum, molybdenum, cobalt, iron, and niobium [5,32].

In this section below, the information on the trace metal ion release in vivo from spinal implants into human bodily fluids (blood, serum, plasma, and urine) of patients is presented.

\subsubsection{Titanium}

In vivo monitoring of titanium release was usually based on the determination of the metal level in blood or serum $[33,34]$. A number of investigations have reported blood/serum titanium levels associated with different types of wellfunctioning and malfunctioning prostheses (hip, knee) and spinal implants. Although most have focused on the toxicity of cobalt and chromium, other studies have also reported issues concerning titanium release from implants [35].

Titanium and its most popular alloys (Ti-Al-V, Ti-Al-Nb) are commonly used metals in orthopedics and most of the modern spinal implants contain titanium and remain in the patient's body permanently, while majority of ions released by Ti implants are Ti(IV) [36].

Lukina et al. [28] in a retrieval of implantation of titanium growth guiding sliding instrumentation (cpTi) for scoliosis in children, found almost 4-fold increase in Ti whole blood concentrations in pediatric patients when compared to the separate control group of patients with no metal implants and was accompanied by clinical manifestations such as seroma and sinuses.

Elevated levels of Ti ion were detected in blood/serum after instrumental spinal arthrodesis implants with titanium alloy implants [37-39]. Richardson et al. [37] reported a significantly higher blood titanium concentration in patients with titanium spinal implants when compared with controls. Ipach et al. [38] also demonstrated increases of Ti content in whole blood, in older patients, after 3 months, and this trend seemed to remain after 12 months. However, the differences in the Ti content in the whole blood of patients after the study period were not statistically significant when compared to the pre-operative level or the concentration in the control group. A retrospective study of serum Ti ion concentrations in patients with titanium alloy spinal implants was performed [39]. Approximately one third of patients with titanium alloy spinal implants exhibited abnormal serum Ti concentrations. However, serum metal concentrations did not seem to be a useful indicator of hardware loosening or implant failure.

In a series of papers, Cundy et al. [40-42] reported that serum concentrations of Ti ion were increased in patients who had spinal implants. The biggest elevation in the serum titanium level in pediatric patients who had undergone a spinal arthrodesis was observed within the first postoperative week, while a later increase was slower, and after six months the Ti concentration started to decrease $[40,41]$. This rapid rise in the serum Ti level was further investigated by the authors [42] and seems to be associated with a release of metal during the implantation, but an elevated Ti level in intraoperative fluids was reported in only two patients.

In a recent prospective study of metal ion release during growth-friendly instrumentation for early-onset scoliosis published by Yilgor et al. [43], they have also reported an increase in serum titanium levels, attributed to implanted spinal instrumentation, higher than controls in all groups of cases. In another, similar report, Danielewicz et al. [44] assessed the influence of the rod fracture on the titanium ion release in traditional growing rods instrumentation for early onset scoliosis. Implanted implants lead to the release of Ti ions into tissues and blood. Mechanical damage to the implant, destabilizing the structure, has no significant effect on the increase of titanium content in the blood and tissues.

Recently, Bances et al. [45] reported a significantly elevated serum titanium level in patients who had Ti spinal implants (posterolateral arthrodesis) for a mean of 1 year. 
In the case of fracture fixation devices, such as intramedullary nails, an elevation of the serum Ti level was observed in patients with implants made of Ti-6Al-4V alloy [46,47]. However, if Ti-6Al-7Nb alloy was used for the fracture fixation, there was no change in the serum Ti level after 1 year from the time of implantation [48].

In addition to hip and knee replacements, other metallic devices in parts of the skeleton are of interest and Gornet et al. [49] measured Ti concentrations in serum from patients with titanium alloy/titanium carbide composite (Ti-6Al$4 \mathrm{~V} / \mathrm{TiC}$ ) cervical disc implants. Insertion of these discs provides a treatment for degenerative cervical disc disease but wear can produce insoluble particulates and soluble metal ions. To assess the release of metal, these authors measured serum Ti concentration at intervals up to 84 months following operation. Concentrations at all time points were significantly higher than preoperatively and stabilized at around 1.2 to $1.4 \mu \mathrm{g} \mathrm{L}-1$ after about 12 months. These concentrations are much lower than in patients with other metal alloy spinal implants.

Very recently, Brembilla et al. [50] reported a slightly elevated serum titanium level in 2 patients who had Ti alloy implants (instrumented spinal arthrodesis) for a six months and ten years, respectively. Their cases presented implant failure and corrosion associated with local metal release evidenced at histopathology; however only slightly elevated metal (Al, Co, Cr, Mo, and Ti) serum levels have been evidenced. This suggest that spinal implant bad-functioning with confirmed local metal release and initial inflammatory local tissue reactions could be underestimated through serum metal measurement.

The total concentrations of titanium in the bodily fluids of patients following ion release from metallic spinal implants are presented in Table 2 .

\subsubsection{Chromium and nickel}

The long-term clinical implications of elevated metal concentrations are still not well understood and require long-term patient surveillance for metal concentrations and any related adverse events. Elevated concentrations of metals, notably $\mathrm{Cr}, \mathrm{Ni}$, and Co levels from stainless steel-based spinal implants, have been reported in the human biological specimens (blood, serum, plasma, or urine) of patients after instrumented spinal fusion [22,23,51-65].

Kim et al. [22] found high serum levels of $\mathrm{Cr}$ and $\mathrm{Ni}$ after posterior spinal arthrodesis using stainless steel implants. High levels of Ni have been noted postoperatively up to $3.8 \mu \mathrm{g} \mathrm{L-1;}$ the levels diminished rapidly with time from surgery but remained above normal levels 4 years after surgery, suggesting that ion levels decrease as fusion occurred. del Rio et al. [23] described similarly elevated serum chromium and nickel levels in patients with instrumented spinal arthrodesis, noting the correlation between significantly higher metal ion levels and radiological signs of device corrosion. Rackham et al. [51] determined that the number of metal connections/interfaces was positively correlated with abnormally elevated serum chromium levels in a group of 30 pediatric patients undergoing posterior spinal arthrodesis.

Several studies have reported metal concentrations, in pediatric and adult subjects implanted with stainless steel posterior spinal instrumentation, that serum Cr levels were higher than the normal reference range [10,52], or higher than levels measured in controls [53,54] more than 4 years after surgery. In contrast, one study [55] found no significant difference in $\mathrm{Cr}$ levels in whole blood among patients with retrained implants, patients with removed implants and unmatched controls. These studies have failed to detect elevated amounts of circulating $\mathrm{Cr}$ or Ni from stainless steel scoliosis rod fixation systems.

Elevated serum $\mathrm{Cr}$ and $\mathrm{Ni}$ levels and visible corrosion were shown in a study on patients treated with a stainless steel modular femoral nail [56,57]. In these papers it was suggested that such levels might serve as a marker of fretting corrosion of these devices, in particular at the modular junctions, even if the clinical impact of elevated ion levels and their association with osteolysis was not fully defined.

Electrochemical and mechanical processes may interact, causing premature structural failure and accelerated release of metal ions, in particular chromium and nickel, which may lead to unfavorable biological reactions [58]. The authors found increased levels of chromium and nickel, as well as a positive correlation between such levels and their sister chromatid exchanges, in a small number of patients with fixation devices. 
Table 1 Quantitation of metallic wear particles in situ isolated in soft tissue of patients adjacent to metallic spinal implants.

\begin{tabular}{|c|c|c|c|c|c|c|c|}
\hline $\begin{array}{l}\text { Instrumentations } \\
\text { used }\end{array}$ & $\begin{array}{l}\text { Time } \\
\text { in situ }\end{array}$ & $\begin{array}{l}\text { No. of } \\
\text { patients }\end{array}$ & Metal & $\begin{array}{l}\text { Metal particle tissue content } \\
\left(\mu g^{-1}\right)\end{array}$ & Detection system & $\begin{array}{l}\text { Wear particles morphology } \\
\text { Clinical outcomes }\end{array}$ & Refs. \\
\hline $\begin{array}{l}\text { Ti-6Al-4V } \\
\text { spinal } \\
\text { instrumentation }\end{array}$ & $1-2 y$ & 3 & $\begin{array}{l}\text { Al } \\
\text { Mo } \\
\text { V } \\
\text { Co }\end{array}$ & $\begin{array}{l}8.4^{*} \\
1.6^{*} \\
0.06^{*} \\
1.35^{*}\end{array}$ & $\begin{array}{l}\text { SEM } \\
\text { ICP-MS } \\
\text { ICP-OES }\end{array}$ & $\begin{array}{l}\text { Tribororrosive process due to both } \\
\text { wear and environmental factors } \\
\text { Dark gray granulation tissue }\end{array}$ & [9] \\
\hline $\begin{array}{l}\text { Titanium pedicle } \\
\text { screw } \\
\text { instrumentation }\end{array}$ & $\mathrm{n} / \mathrm{a}$ & 9 & $\mathrm{Ti}$ & $\begin{array}{l}30.36^{* \prime}(1.15-119.38) \\
45.80^{* \prime}(2.69-130.61)\end{array}$ & $\begin{array}{l}\text { GF-AAS } \\
\text { TEM }\end{array}$ & $\begin{array}{l}\text { Rod-like profiles bearing resemblance } \\
\text { to metal particles } \\
\text { Pseudarthrosis develops }\end{array}$ & [27] \\
\hline $\begin{array}{lr}\text { Ti-6Al-4V } & \text { sliding } \\
\text { growth } & \text { guidance } \\
\text { instrument } & \end{array}$ & $6 y$ & 25 & $\begin{array}{l}\mathrm{Ti} \\
\mathrm{Al} \\
\mathrm{V}\end{array}$ & $\begin{array}{l}1300^{* *}(103-5750) \\
18^{* *}(2-106) \\
11^{* *}(2-109)\end{array}$ & ICP-MS & $\begin{array}{l}\text { Titanium particles appear black in } \\
\text { stained histological sections } \\
\text { Metallosis-associated clinical } \\
\text { complications; clinical manifestations } \\
\text { such as seroma and sinuses }\end{array}$ & [28] \\
\hline $\begin{array}{l}\text { Stainless steel } \\
\text { plates/316L }\end{array}$ & $1 \mathrm{y}$ & 14 & $\begin{array}{l}\mathrm{Fe} \\
\mathrm{Cr} \\
\mathrm{Ni} \\
\mathrm{Mo} \\
\mathrm{Ti} \\
\mathrm{Fe} \\
\mathrm{Cr} \\
\mathrm{Ni} \\
\mathrm{Mo} \\
\mathrm{Ti}\end{array}$ & $\begin{array}{l}1106^{*}(238-2840) \\
92.7^{*}(8.4-304.5) \\
46.3^{*}(2.8-1851) \\
14.1^{*}(1.1-42.3) \\
2.6^{*}(0.3-9.8) \\
437.7^{*}(75.8-890.5) \\
6.5^{*}(1.9-22.6) \\
8.6^{*}(1.6-23.4) \\
11.1^{*}(0.7-42.3) \\
76.6^{*}(10.4-201)\end{array}$ & ICP-OES & $\begin{array}{l}\text { Tendon-like or scar tissue } \\
\text { Tissue discolorations } \\
\text { The increased release of toxic, allergic, } \\
\text { and potentially carcinogenic ions } \\
\text { adjacent to stainless steel }\end{array}$ & {$[30]$} \\
\hline $\begin{array}{l}\text { Growing spinal } \\
\text { implants }\end{array}$ & $\mathrm{n} / \mathrm{a}$ & 3 & $\mathrm{Ti}$ & $0.11-0.38$ & GF-AAS & $\mathrm{n} / \mathrm{a}$ & {$[31]$} \\
\hline
\end{tabular}

Analytical techniques: SEM, scanning electron microscopy; ICP-MS, inductively coupled plasma mass spectrometry; ICP-OES, inductively coupled plasma optical emission spectrometry; GF-AAS, graphite furnace atomic absorption spectrometry; TEM, transmission electron microscopy;

Results are reported as mean*/median** concentration, range (in parentheses); $\mathrm{n} / \mathrm{a}$ - data not available; $\mathrm{y}$-year 
Table 2 In vivo times and Ti total concentration in bodily fluids of patients following ion release from metallic spinal implants

\begin{tabular}{|c|c|c|c|c|c|c|c|c|c|c|}
\hline \multirow[t]{2}{*}{$\begin{array}{l}\text { Instrumentations } \\
\text { used }\end{array}$} & \multirow[t]{2}{*}{$\begin{array}{l}\text { Time } \\
\text { in vivo }\end{array}$} & \multirow[t]{2}{*}{$\begin{array}{l}\text { No. of } \\
\text { patients }\end{array}$} & \multirow{2}{*}{$\begin{array}{l}\text { Bodily } \\
\text { fluid } \\
\text { analyzed }\end{array}$} & \multirow{2}{*}{$\begin{array}{l}\text { Metal } \\
\text { ion(s) } \\
\text { measured }\end{array}$} & \multicolumn{2}{|c|}{$\begin{array}{l}\text { Concentration }\left(\mu \mathrm{g} \mathrm{L}^{-}\right. \\
\text {1) }\end{array}$} & \multirow[t]{2}{*}{$\begin{array}{l}\text { Median ( } \mu \mathrm{g} \\
\left.\mathrm{L}^{-1}\right)\end{array}$} & \multirow[t]{2}{*}{$\begin{array}{l}\text { Analytical } \\
\text { technique }\end{array}$} & \multirow[t]{2}{*}{ Clinical outcomes } & \multirow[t]{2}{*}{ Refs. } \\
\hline & & & & & $\begin{array}{l}\text { Metal } \\
\text { implant }\end{array}$ & Control & & & & \\
\hline $\begin{array}{l}\text { Ti-6Al-4V sliding } \\
\text { growth guidance } \\
\text { instrument }\end{array}$ & $6 y$ & 25 & $\begin{array}{l}\text { Whole } \\
\text { blood }\end{array}$ & $\begin{array}{l}\mathrm{Ti} \\
\mathrm{Al}\end{array}$ & & & $\begin{array}{l}85 \\
(28-180) \\
30 \\
(18-150) \\
0.3 \\
(0.2-0.5)\end{array}$ & ICP-MS & $\begin{array}{l}90 \% \text { had increased Ti compared to } \\
\text { controls. Incidence of metallosis- } \\
\text { related clinical complications in } \\
20 \% \text { of patients; clinical } \\
\text { manifestations such as seroma or } \\
\text { sinuses without inflammation }\end{array}$ & {$[28]$} \\
\hline $\begin{array}{l}\text { Titanium alloy } \\
\text { instrumented } \\
\text { spinal arthrodesis }\end{array}$ & $\begin{array}{l}23-28 \\
m\end{array}$ & 30 & Serum & $\mathrm{Ti}$ & $\begin{array}{l}2.6 \\
(0.48- \\
12.97)\end{array}$ & $\begin{array}{l}0.707 \\
(0.36- \\
1.58)\end{array}$ & & $\begin{array}{l}\text { (HR) ICP- } \\
\text { MS }\end{array}$ & $\begin{array}{l}\text { Changes in abnormally elevated } \\
\text { serum } \mathrm{Ti} \text { concentrations ( } 4 \text {-fold } \\
\text { increases compared with control } \\
\text { group): } 368 \%\end{array}$ & [37] \\
\hline $\begin{array}{l}\text { Titanium alloy } \\
\text { instrumentation }\end{array}$ & $2 d-1 y$ & 15 & $\begin{array}{l}\text { Whole } \\
\text { blood }\end{array}$ & $\mathrm{Ti}$ & $\begin{array}{l}55.1 \\
(31.0- \\
142.0)\end{array}$ & $\begin{array}{l}47.9 \\
(32.0- \\
69.0)\end{array}$ & & ICP-MS & $\begin{array}{l}\text { Changes in whole blood } \mathrm{Ti} \\
\text { concentration ( } 2 \text { to } 3 \text {-fold increases, } \\
\text { compared with samples taken pre- } \\
\text { operatively): } 115 \%\end{array}$ & [38] \\
\hline $\begin{array}{l}\mathrm{Ti} \text { alloy lumbar } \\
\text { spinal implants }\end{array}$ & $5.1 \mathrm{y}$ & 16 & Serum & $\begin{array}{l}\mathrm{Ti} \\
\mathrm{Al}\end{array}$ & $\begin{array}{l}79(65-90) \\
50-90\end{array}$ & $\begin{array}{l}80(60- \\
90)\end{array}$ & & ICP-OES & $\begin{array}{l}\text { One third ( } 34.8 \%) \text { of patients with } \mathrm{Ti} \\
\text { alloy spinal implants exhibited } \\
\text { abnormal serum Ti concentrations } \\
\text { (4-fold increases). Implant failure } \\
\text { due to pedicle screw loosening }\end{array}$ & [39] \\
\hline $\begin{array}{l}\text { Ti-6Al-7Nb alloy } \\
\text { instrumentation }\end{array}$ & $\begin{array}{l}1 w-1 \\
y\end{array}$ & 33 & Serum & $\mathrm{Ti}$ & $\begin{array}{l}1.84 \\
(0.56-9.89)\end{array}$ & $\begin{array}{l}0.28 \\
(0.05- \\
0.70)\end{array}$ & 1.65 & $\begin{array}{l}(\mathrm{HR}) \text { ICP- } \\
\mathrm{MS}\end{array}$ & $\begin{array}{l}\text { Changes in serum Ti concentrations } \\
\text { (compared with samples taken pre- } \\
\text { operatively): } 514 \% \text { ( } 1 \text { week), } 604 \% \\
\text { (1 year) }\end{array}$ & {$[40]$} \\
\hline $\begin{array}{l}\mathrm{Ti}-6 \mathrm{Al}-7 \mathrm{Nb} \text { alloy } \\
\text { instrumentation }\end{array}$ & $\begin{array}{l}1 w-1 \\
y\end{array}$ & 32 & Serum & $\begin{array}{l}\mathrm{Ti} \\
\mathrm{Al}\end{array}$ & $\begin{array}{l}1.83 \\
1.17\end{array}$ & $\begin{array}{l}0.20 \\
0.23\end{array}$ & $\begin{array}{l}1.75 \\
1.00\end{array}$ & $\begin{array}{l}(\mathrm{HR}) \quad \mathrm{ICP}- \\
\mathrm{MS}\end{array}$ & $\begin{array}{l}\text { Changes in serum Ti concentrations } \\
\text { (compared with samples taken pre- } \\
\text { operatively): } 526 \% \text { ( } 1 \text { week), } 641 \%\end{array}$ & {$[41]$} \\
\hline
\end{tabular}


World Journal of Advanced Research and Reviews, 2021, 09(03), 167-187

\begin{tabular}{|c|c|c|c|c|c|c|c|c|c|c|}
\hline & & & & $\mathrm{Nb}$ & 0.23 & 0.16 & 0.21 & & $\begin{array}{l}\text { (1 month), } 678 \% \text { ( } 6 \text { months), } 626 \% \\
\text { (1 year), 611\% ( } 2 \text { years). Strong } \\
\text { association between surface area of } \\
\text { implant and Ti levels }\end{array}$ & \\
\hline $\begin{array}{l}\mathrm{Ti}-6 \mathrm{Al}-7 \mathrm{Nb} \text { alloy } \\
\text { instrumentation }\end{array}$ & $1-28 d$ & 2 & Serum & $\begin{array}{l}\mathrm{Ti} \\
\mathrm{Nb} \\
\mathrm{Al}\end{array}$ & $\begin{array}{l}2.5 ; 4.1 \\
0.25 ; 0.31 \\
1.1 ; 3.0\end{array}$ & $\begin{array}{l}0.1 \\
0.02 \\
0.4 ; 2.2\end{array}$ & & $\begin{array}{l}(\mathrm{HR}) \text { ICP- } \\
\text { MS }\end{array}$ & $\begin{array}{l}\text { Higher serum Ti level (compared } \\
\text { to samples taken pre-operatively) }\end{array}$ & [42] \\
\hline $\begin{array}{l}\mathrm{Ti}-6 \mathrm{Al}-4 \mathrm{~V} \text { alloy } \\
\text { instrumentation }\end{array}$ & $54 \mathrm{~m}$ & 更 & $\begin{array}{l}\text { Serum } \\
\text { GR }\end{array}$ & $\begin{array}{l}\mathrm{Ti} \\
\mathrm{Al} \\
\mathrm{V} \\
\mathrm{Ti} \\
\mathrm{Al}\end{array}$ & $\begin{array}{l}7.3 \\
8.1 \\
0.2 \\
10.2 \\
7.8 \\
0.5\end{array}$ & $\begin{array}{l}2.8 \\
5.4 \\
0.2 \\
2.8 \\
5.4 \\
0.2\end{array}$ & $\begin{array}{l}7.28 \\
(1.2-18.7) \\
3.83 \\
(3.08-24.3) \\
0.16 \\
(0.11-0.24) \\
8.79 \\
(4.11-27.1) \\
6.20 \\
(1.33-17.1) \\
0.32 \\
(0.13-1.98)\end{array}$ & ICP-MS & $\begin{array}{l}\text { Local long-term clinical effects of } \\
\text { increased metal ion levels remain } \\
\text { undetermined. GR and MCGR Ti } \\
\text { levels were significantly increased } \\
\text { compared to controls }\end{array}$ & [43] \\
\hline $\begin{array}{l}\mathrm{Ti}-6 \mathrm{Al}-4 \mathrm{~V} \text { alloy } \\
\text { instrumentation }\end{array}$ & $1 \mathrm{y}$ & 19 & Serum & $\mathrm{Ti}$ & 2.5406 & 0.7449 & & $\begin{array}{l}\text { (DF) ICP- } \\
\text { MS }\end{array}$ & $\begin{array}{l}3.5 \text {-fold increase of serum } \mathrm{Ti} \\
\text { concentrations with respect to the } \\
\text { concentrations initially detected } \\
\text { before surgery }\end{array}$ & [44] \\
\hline $\begin{array}{l}\text { Intramedullary } \\
\text { nails }\end{array}$ & $\begin{array}{l}21 \\
329 \mathrm{~m}\end{array}$ & 41 & Serum & $\mathrm{Ti}$ & & & $\begin{array}{l}6.45 \\
(3.38-7.65)\end{array}$ & ICP-MS & $\begin{array}{l}\text { Elevation of serum } \mathrm{Ti} \text { levels were } \\
\text { less statistically significant }\end{array}$ & [47] \\
\hline
\end{tabular}


World Journal of Advanced Research and Reviews, 2021, 09(03), 167-187

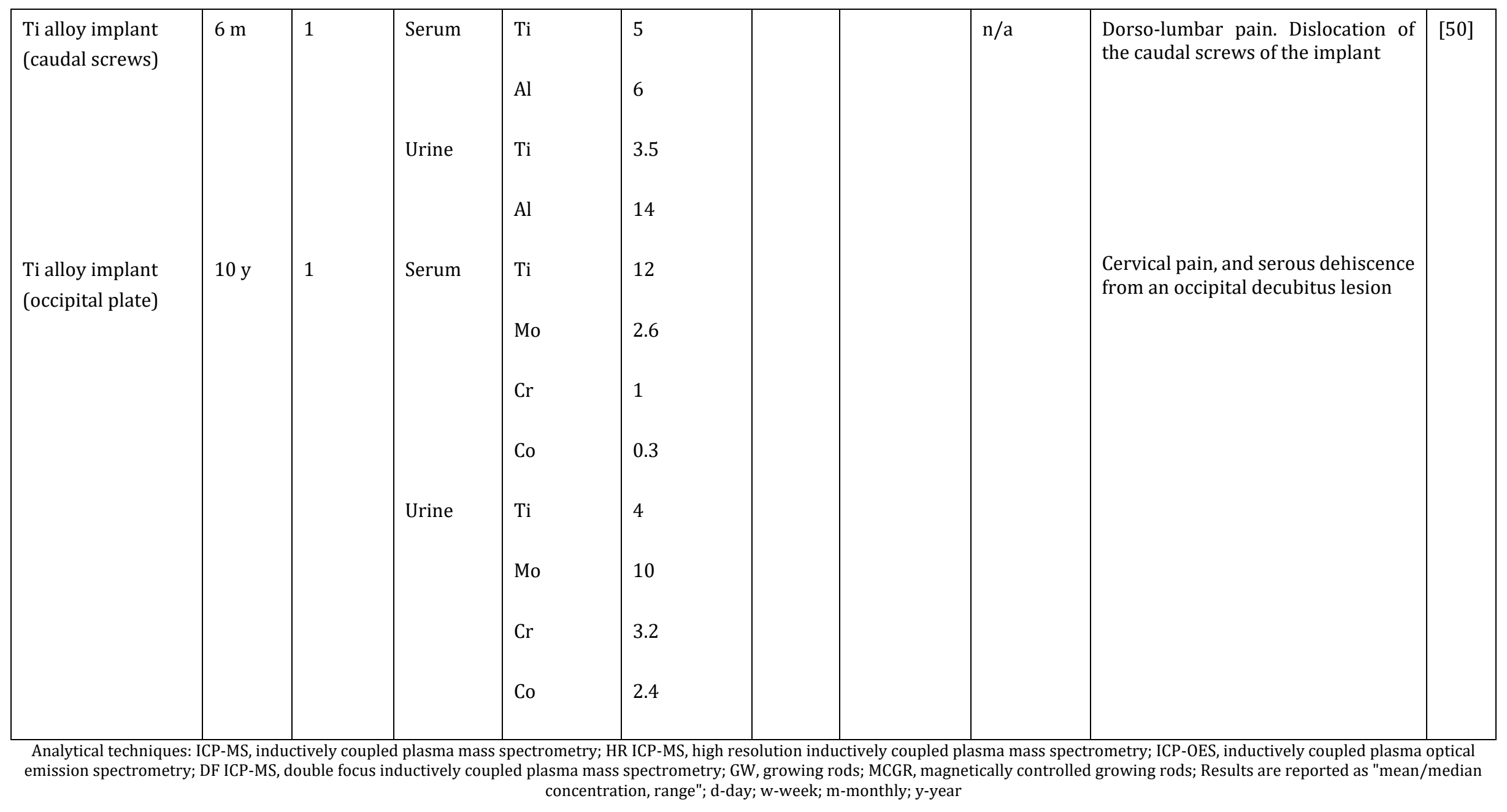


Table 3 In vivo times and $\mathrm{Cr}$ total concentration in bodily fluids of patients following ion release from metallic spinal implants.

\begin{tabular}{|c|c|c|c|c|c|c|c|c|c|c|}
\hline \multirow[t]{2}{*}{$\begin{array}{c}\text { Instrumentations } \\
\text { used }\end{array}$} & \multirow[t]{2}{*}{$\begin{array}{l}\text { Time } \\
\text { in vivo }\end{array}$} & \multirow[t]{2}{*}{$\begin{array}{c}\text { No. of } \\
\text { patients }\end{array}$} & \multirow{2}{*}{$\begin{array}{c}\text { Bodily } \\
\text { fluid } \\
\text { analyzed }\end{array}$} & \multirow{2}{*}{$\begin{array}{c}\text { Metal } \\
\text { ion(s) } \\
\text { measured }\end{array}$} & \multicolumn{2}{|c|}{$\begin{array}{c}\text { Concentration }\left(\mu \mathrm{g} \mathrm{L}^{-}\right. \\
1 \text { ) }\end{array}$} & \multirow[t]{2}{*}{$\begin{array}{l}\text { Median } \\
\left(\mu \mathrm{g} \mathrm{L}^{-1}\right)\end{array}$} & \multirow[t]{2}{*}{$\begin{array}{l}\text { Analytical } \\
\text { technique }\end{array}$} & \multirow[t]{2}{*}{ Clinical outcomes } & \multirow[t]{2}{*}{ Refs. } \\
\hline & & & & & $\begin{array}{c}\text { Metal } \\
\text { implant }\end{array}$ & Control & & & & \\
\hline $\begin{array}{l}\text { Posterior spinal } \\
\quad \text { fusion SS } \\
\text { instrumentation }\end{array}$ & $4 y$ & 1 & serum & $\mathrm{Cr}$ & 4.5 & $\begin{array}{l}0.2- \\
0.6\end{array}$ & & $\mathrm{n} / \mathrm{a}$ & $\begin{array}{l}\text { Progressive pain. Metallosis within } \\
\text { the spinal canal was noted. Peak } 4.5 \\
\mu \mathrm{g} \mathrm{L}^{-1} \text { in symptomatic patient; } \\
\text { decrease to } 3.6 \mu \mathrm{L} \mathrm{L}^{-1} \text { at } 1 \text { week after } \\
\text { instrumentation removed and } \\
\text { improved to } 0.8 \mu \mathrm{g} \mathrm{L}^{-1} \text { at } 3 \text { years } \\
\text { after instrumentation removed but } \\
\text { still elevated above the normal range }\end{array}$ & [10] \\
\hline $\begin{array}{l}\text { Posterior spinal } \\
\text { arthrodesis with } \\
\text { SS } \\
\text { instrumentation }\end{array}$ & $3.9 y$ & 37 & serum & $\mathrm{Cr}$ & 2.7 & 0.3 & & ICP-MS & $\begin{array}{l}\text { Cr levels remained above normal } \\
\text { levels at } 4 \text { years. Inverse correlation } \\
\text { between serum } \mathrm{Cr} \text { and time since } \\
\text { surgery }\end{array}$ & {$[22]$} \\
\hline $\begin{array}{l}\text { Posterior spinal } \\
\text { arthrodesis with } \\
\text { SS } \\
\text { instrumentation }\end{array}$ & $31.8 \mathrm{y}$ & 11 & $\begin{array}{l}\text { serum } \\
\text { urine }\end{array}$ & $\mathrm{Cr}$ & & & $\begin{array}{c}10.5 \\
(1.6-33.0) \\
\\
27.9 \\
(6.0-96.5)\end{array}$ & AAS & $\begin{array}{l}\text { Cr levels in asymptomatic patients } \\
\text { with radiological signs of corrosion } \\
\text { were elevated compared to Cr levels } \\
\text { in patients with implants and no } \\
\text { corrosion and patients controls } \\
\mathrm{Cr}>3.75 \mu \mathrm{g} \mathrm{L}^{-1} \text { indicates corrosion in } \\
\text { asymptomatic patients }\end{array}$ & {$[23]$} \\
\hline $\begin{array}{l}\text { Intramedullary } \\
\text { nails }\end{array}$ & $\begin{array}{c}21-329 \\
m\end{array}$ & 41 & serum & $\begin{array}{l}\text { Cr } \\
\text { Al } \\
\text { Mo }\end{array}$ & & & $\begin{array}{c}0.10 \\
(0.04- \\
0.22) \\
\\
2.55 \\
(0.73- \\
4.05) \\
\\
0.75 \\
(0.35- \\
1.25)\end{array}$ & $\begin{array}{l}\text { ICP-MS } \\
\text { ICP-OES } \\
\text { ICP-MS }\end{array}$ & $\begin{array}{l}\text { Significant elevation in serum } \mathrm{Cr} \text { in } \\
\text { the Russel-Taylor nails, with median } \\
\text { concentrations that were } 2.5 \text { times } \\
\text { higher than those in the control } \\
\text { group }\end{array}$ & [47] \\
\hline $\begin{array}{l}\text { Posterior spinal } \\
\text { arthrodesis with } \\
\text { SS } \\
\text { instrumentation }\end{array}$ & $4 y$ & 30 & serum & $\mathrm{Cr}$ & 0.97 & & $\begin{array}{c}0.96 \\
(0.26-9.4) \\
\mathrm{nmol} \mathrm{L}^{-1}\end{array}$ & GF-AAS & $\begin{array}{l}37 \% \text { of patients had elevated serum } \\
\mathrm{Cr} \text { above reference range. Positive } \\
\text { association between implant area } \\
\text { and serum } \mathrm{Cr}\end{array}$ & [51] \\
\hline
\end{tabular}




\begin{tabular}{|c|c|c|c|c|c|c|c|c|c|c|}
\hline Harrington rods & $4 y$ & 1 & plasma & $\mathrm{Cr}$ & 1.39 & & & $\mathrm{n} / \mathrm{a}$ & $\begin{array}{l}\text { Pain, disability, and peripheral } \\
\text { muscle weakness and atrophy. } \\
\text { Raynaud's phenomenon. Elevated Cr } \\
\text { levels above normal reference were } \\
\text { associated with metallosis }\end{array}$ & [52] \\
\hline $\begin{array}{c}\text { SS } \\
\text { instrumentation }\end{array}$ & $19.4 \mathrm{y}$ & 22 & serum & $\mathrm{Cr}$ & & & $\begin{array}{c}0.36 \\
(0.10- \\
2.46)\end{array}$ & GF-AAS & $\begin{array}{l}\text { Serum } \mathrm{Cr} \text { increased compared to } \\
\text { controls. High risk of failure if } \mathrm{Cr}>0.6 \\
\mu \mathrm{g} \mathrm{L}^{-1}\end{array}$ & [54] \\
\hline $\begin{array}{c}\text { SS posterior } \\
\text { instrumentation }\end{array}$ & $9.3 \mathrm{y}$ & 32 & $\begin{array}{l}\text { whole } \\
\text { blood }\end{array}$ & $\mathrm{Cr}$ & $\begin{array}{c}0.57 \\
0.88-0.94\end{array}$ & & $\begin{array}{c}0.35 \\
(0.06-2.8)\end{array}$ & GF-AAS & $\begin{array}{l}\text { No difference in } \mathrm{Cr} \text { levels between } \\
\text { groups (implant retained } v s \text {. implant } \\
\text { removed) }\end{array}$ & [55] \\
\hline $\begin{array}{l}\text { SS femoral } \\
\text { intramedullary } \\
\text { nails }\end{array}$ & $\begin{array}{c}21-26 \\
m\end{array}$ & 27 & serum & $\mathrm{Cr}$ & $\begin{array}{c}1.27 \\
(0.34-3.12)\end{array}$ & $\begin{array}{c}0.05 \\
(0.015- \\
0.25)\end{array}$ & & Spectrograph & $\begin{array}{l}\text { Serum } \mathrm{Cr} \text { levels substantially } \\
\text { elevated in the patients with a } \\
\text { modular femoral nail; serve as a } \\
\text { marker of fretting corrosion }\end{array}$ & [56] \\
\hline $\begin{array}{c}\text { SS fracture } \\
\text { fixation devices }\end{array}$ & $\begin{array}{c}24-62 \\
m\end{array}$ & 45 & serum & $\mathrm{Cr}$ & $0.59-2.04$ & 0.18 & & GF-AAS & $\begin{array}{l}\text { Pain, pseudoarthrosis, or loosing } \\
\text { were found as causes of failure }\end{array}$ & [58] \\
\hline $\begin{array}{c}\text { SS fracture } \\
\text { fixation devices }\end{array}$ & $\mathrm{n} / \mathrm{a}$ & 10 & serum & $\begin{array}{l}\mathrm{Cr} \\
\mathrm{Co}\end{array}$ & $\begin{array}{l}1.10-2.2 \\
3.3-4.75\end{array}$ & $\begin{array}{l}0.19 \\
0.20\end{array}$ & & GF-AAS & $\begin{array}{l}\text { No correlation was found between } \\
\text { the increased Cr concentrations and } \\
\text { the sister chromatid exchange } \\
\text { number while Cr ion levels were } \\
\text { found to be significantly correlated } \\
\text { to high frequency cell numbers }\end{array}$ & [59] \\
\hline $\begin{array}{l}\text { Single-level } \\
\text { lumbar disc }\end{array}$ & $\begin{array}{c}12-36 \\
m\end{array}$ & 24 & serum & $\begin{array}{l}\mathrm{Cr} \\
\mathrm{Co}\end{array}$ & & & $\begin{array}{c}0.06-0.65 \\
0.074- \\
0.274 \\
\end{array}$ & ICP-MS & $\begin{array}{l}\text { All of the postoperative } \mathrm{Cr} \text { levels } \\
\text { were higher than the preoperative } \\
\text { levels }\end{array}$ & [63] \\
\hline $\begin{array}{l}\text { SS cervical disc } \\
\text { system }\end{array}$ & $\begin{array}{c}3-84 \\
\mathrm{~m}\end{array}$ & 25 & serum & $\mathrm{Cr}$ & & & $\begin{array}{c}0.074- \\
0.203\end{array}$ & ICP-MS & $\begin{array}{l}\text { Cr concentration at all time periods } \\
\text { were statistically higher than the } \\
\text { preoperative concentration }\end{array}$ & [64] \\
\hline SS pectus bars & $13 \mathrm{~m}$ & 11 & serum & $\begin{array}{l}\text { Cr } \\
\text { Mo }\end{array}$ & & & $\begin{array}{c}0.22- \\
12.30 \\
0.66-2.43\end{array}$ & ICP-MS & $\begin{array}{l}\text { Median serum } \mathrm{Cr} \text { value is } \\
\text { significantly elevated } 3.3 \text {-fold above } \\
\text { the control group. Chromium levels } \\
\text { is abnormally elevated in } 6(55 \%) \text { of } \\
11 \text { patients }\end{array}$ & [66] \\
\hline
\end{tabular}
furnace atomic absorption spectrometry; Results are reported as "mean/median concentration, range"; n/a - data not available; m-month; y-year 
Table 4 In vivo times and Ni total concentration in bodily fluids of patients following ion release from metallic spinal implants.

\begin{tabular}{|c|c|c|c|c|c|c|c|c|c|c|}
\hline \multirow[t]{2}{*}{$\begin{array}{l}\text { Instrumentations } \\
\text { used }\end{array}$} & \multirow[t]{2}{*}{$\begin{array}{l}\text { Time } \\
\text { in vivo }\end{array}$} & \multirow[t]{2}{*}{$\begin{array}{c}\text { No. of } \\
\text { patients }\end{array}$} & \multirow{2}{*}{$\begin{array}{c}\text { Bodily } \\
\text { fluid } \\
\text { analyzed }\end{array}$} & \multirow{2}{*}{$\begin{array}{c}\text { Metal } \\
\text { ion(s) } \\
\text { measured }\end{array}$} & \multicolumn{2}{|c|}{$\begin{array}{c}\text { Concentration }\left(\mu \mathrm{g} \mathrm{L}^{-}\right. \\
1)\end{array}$} & \multirow[t]{2}{*}{$\begin{array}{l}\text { Median } \\
\left(\mu \mathrm{g} \mathrm{L}^{-1}\right)\end{array}$} & \multirow[t]{2}{*}{$\begin{array}{l}\text { Analytical } \\
\text { technique }\end{array}$} & \multirow[t]{2}{*}{ Clinical outcomes } & \multirow[t]{2}{*}{ Refs. } \\
\hline & & & & & $\begin{array}{c}\text { Metal } \\
\text { implant }\end{array}$ & Control & & & & \\
\hline $\begin{array}{l}\text { Posterior spinal } \\
\text { arthrodesis with } \\
\text { SS } \\
\text { instrumentation }\end{array}$ & $3.9 \mathrm{y}$ & 37 & serum & $\mathrm{Ni}$ & 3.8 & 0.3 & & ICP-MS & $\begin{array}{l}\mathrm{Ni} \text { levels remained above normal } \\
\text { levels at } 4 \text { years }\end{array}$ & {$[22]$} \\
\hline $\begin{array}{l}\text { Posterior spinal } \\
\text { arthrodesis with } \\
\text { SS } \\
\text { instrumentation }\end{array}$ & $31.8 \mathrm{y}$ & 11 & urine & $\mathbf{N i}$ & & & $\begin{array}{c}3.80 \\
(1.50-9.00) \\
\\
20.40 \\
(1.70- \\
300.00) \\
\end{array}$ & GF-AAS & $\begin{array}{l}\text { Ni was increased when compared to } \\
\text { patients with no radiological signs of } \\
\text { corrosion and to volunteers without } \\
\text { implants }\end{array}$ & {$[23]$} \\
\hline $\begin{array}{c}\text { SS } \\
\text { instrumentation } \\
\end{array}$ & $19.4 \mathrm{y}$ & 22 & serum & $\mathrm{Ni}$ & $\begin{array}{c}0.56 \\
(0.10-1.01)\end{array}$ & & & GF-AAS & $\begin{array}{l}\text { No difference between groups were } \\
\text { found for } \mathrm{Ni} \text { (patients vs. control) }\end{array}$ & {$[54]$} \\
\hline $\begin{array}{c}\text { SS posterior } \\
\text { instrumentation }\end{array}$ & $9.4 \mathrm{y}$ & 32 & $\begin{array}{l}\text { whole } \\
\text { blood }\end{array}$ & $\mathrm{Ni}$ & $0.88-1.17$ & & & Spectrograph & $\begin{array}{l}\text { No difference between } \text { groups } \\
\text { (implant retained vs. implant } \\
\text { removed) }\end{array}$ & {$[56]$} \\
\hline $\begin{array}{c}\text { SS fracture } \\
\text { fixation devices }\end{array}$ & $\begin{array}{c}24-62 \\
m\end{array}$ & 45 & serum & $\mathrm{Ni}$ & $0.49-0.76$ & & & GF-AAS & $\begin{array}{l}\text { Pain, pseudoarthrosis, or loosing } \\
\text { were found as causes of failure }\end{array}$ & [57] \\
\hline $\begin{array}{c}\text { SS fracture } \\
\text { fixation devices }\end{array}$ & $\mathrm{n} / \mathrm{a}$ & 10 & serum & $\mathrm{Ni}$ & 1.71 & 0.72 & & GF-AAS & $\begin{array}{l}\text { An inverse correlation between } \mathrm{Ni} \\
\text { level and sister chromatid exchange } \\
\text { number }\end{array}$ & {$[58]$} \\
\hline $\begin{array}{c}\text { Ni-Ti superelastic } \\
\text { rods } \\
\text { Conventional } \\
\text { titanium alloy } \\
\text { rods }\end{array}$ & $5 y$ & 20 & serum & $\mathrm{Ni}$ & $\begin{array}{l}1.2-2.1 \\
1.2-1.3\end{array}$ & $\begin{array}{l}1.3 \\
1.3\end{array}$ & & $\mathrm{n} / \mathrm{a}$ & $\begin{array}{l}\text { Nickel levels remained within } \\
\text { normal range }\end{array}$ & [65] \\
\hline SS pectus bars & $13 \mathrm{~m}$ & 11 & serum & $\mathrm{Ni}$ & & & $0.14-11.60$ & ICP-MS & $\begin{array}{l}\text { Median serum Ni value is elevated } \\
2.3 \text {-fold above the control group; } \\
\text { however, this is not statistically } \\
\text { significant }\end{array}$ & {$[66]$} \\
\hline
\end{tabular}

Analytical techniques: ICP-MS, inductively coupled plasma mass spectrometry; GF-AAS, graphite furnace atomic absorption spectrometry; Results are reported as "mean/median concentration, range"; n/a - data not available; m-month; y-year 
A recent alternative treatment to fusion for degenerative lumber disc disease is total disc arthroplasty. Common materials used for spinal bearing articulations include metal-on-polyethylene (MoP) and metal-on-metal (MoM) combinations. There have been only a few retrospective reports of metal ion levels in patients with stainless steel MoM disc arthroplasty [59-63]. Recent studies by Zeh et al. [59,60] of MoM TDA find serum levels of cobalt and chromium after TDA are elevated at concentrations of 3-4 $\mu \mathrm{g} \mathrm{L-1}$ for cobalt and 1-2 $\mu \mathrm{g} \mathrm{L-1}$ for chromium, which were significantly elevated over control values The concentrations of circulating $\mathrm{Cr} / \mathrm{Co}$ measured in the serum of people with a MoM TDA are similar to levels measured in well functioning MoM total hip arthroplasties. They reported on a cohort of patients implanted with the Maverick where 5 patients obtained 2 TDAs and 5 patients obtained 1 TDA at two time points (average 14.8 and 36.7 months). The long-term effects of presumably much higher elevations of metal proximal to the spinal implant remain unknown and are under careful surveillance by implant companies, the FDA and orthopedic researchers [61]. Bisseling et al. [62] reported lower serum metal (Cr, Co) levels for a retrospective study of ten patients with a single-level LDA at one postoperative time point averaging 34.5 months (13-61 months). Both Zeh et al. [59] and Bisseling et al. [62] reported on the same device studied in the present series with either one or two time periods postoperatively.

Gornet et al. [63] measured concentrations of cobalt and chromium in the serum of patients who underwent a single level lumbar total disc replacement with a CoCr MoM implant, at 12 and 24 months after surgery, were equal to or lower for $\mathrm{Cr}$ than those associated with stainless steel posterior spinal instrumentation reported by Kim et al. [22], del Rio et al. [23], and McPhee et al. [55]. Cervical disc arthroplasty (CDA) has emerged as an alternative to anterior cervical discectomy and fusion for degenerative cervical disc disease. Serum chromium and nickel concentrations were assessed in 25 patients implanted with ball-in-trough stainless steel-based cervical disc through 7 years. Blood serum $\mathrm{Cr}$ and $\mathrm{Ni}$ concentrations were assayed preoperatively and at 3,6,12, 24, 36, 60, and 84 months postoperatively [64]. The serum $\mathrm{Cr}$ concentrations were statistically higher for all postoperative time periods compared to preoperative concentrations, whereas Ni concentration was statistically higher than the preoperative concentration only at 84 months.

Cheung et al. [65] compared nickel levels after spinal fusion using superelastic nickel-titanium rods to conventional titanium rods. Ni-concentrations varied between 0.6 and $1.3 \mu \mathrm{g} \mathrm{L}-1$ at baseline to $0.6-3.8 \mu \mathrm{g} \mathrm{L}-1$ at 4 or more years after surgery. Cundy et al. [66] investigated serum metal ( $\mathrm{Cr}, \mathrm{Ni}$, and $\mathrm{Mo}$ ) levels in children with implanted pectus bars after minimally invasive repair of pectus excavatum. The results of this study indicated elevated serum chromium and nickel levels in children with implanted pectus bars, in comparison with control patients. No acute metal toxicity was observed.

The total concentrations of chromium and nickel in the bodily fluids of patients following ion release from metallic spinal implants are presented in Table 3 and Table 4.

\section{Clinical reactions to spinal implant debris}

The release of particulate debris from spinal instrumentation remains a clinical concern [67]. Implant debris from wear cause local inflammation, osteolysis, hypersensitivity and granulomatous invasion of bone-implant contact that, over time, results in implant loosening and pain, necessitating revision arthroplasty. Fretting corrosion and histopathologic consequences of debris from metallic spinal instrumentation were reported nearly a quarter of a century ago [19]. Recent reports have documented the effects of spinal implant debris on local tissue and clinical outcome of posterolateral arthrodesis procedures [68]. Authors conducted a large scale retrospective analysis of 190 patients with instrumentation for posterior scoliosis and demonstrated that the most common (18\%) reason for reoperation was the onset of so-called late operative site pain (LOSP) of unknown specific etiology. However, at the time of revision, evidence of fretting corrosion was visible at component connections. This evidence took the form of tissue discoloration with the presence of intracellular metallic particulates debris identified using electron microscopy. Further evidence of fretting corrosion at these locations has been supported by reports that aseptic granulomatous inflammation typical of that associated with corrosion debris appears to correlate with the complexity of the instrumentation [67].

Biologic reactivity to spinal implant debris has been clinically observed with all the hallmarks of traditional particleinduced osteolysis [69]. When osteolysis or granulomas occur in the presence of metal debris, it is termed particle disease. In the case of metal debris, this is often accompanied by metallosis. Metallosis often accompanies metal implant debris-related osteolysis, aseptic fibrosis, local necrosis, or loosening. In a cohort of 12 loosened spinal implant cases, metallosis of the internal membrane was associated with the outer layer of membrane containing an infiltrate of leukocytes and macrophages. All 12 patients had radiolucency around part of the spinal instrumentation. Seven of the patients had titanium implants and 5 of the patients had stainless steel implants, showing this phenomenon is not limited to 1 type of material. The focal areas of osteolysis most commonly involved loose transverse connectors. Resection of the wear debris stained tissue and surrounding fibro-inflammatory zones resulted in resolution of clinical symptoms in all 12 cases [69]. Although stainless steel is more prone to fretting corrosion than titanium, titanium spinal 
devices have been reported to release substantial amounts of metal debris [27]. This metal debris has been reported as greater in patients with pseudarthrosis than in patients with solid fusions. Titanium debris from spinal instrumentation has been associated with activated cellular responses such as macrophage infiltrates much like those found around total joint replacements.

One of the central issues surrounding current metallic spinal implants is the fretting corrosion event observed in the connections of retrieved screw-plate interfaces and modular connections of spinal implant components. Screw-plate investigations [69] have shown that crevices formed at the screw-plate junction are inherent to the geometry of the screw-plate interface and that preventing fretting corrosion may not be possible through enhanced surgical technique. Although screw-plate fretting is a common source of corrosion debris, in modern practice, gross evidence of corrosion in screw-plate interfaces is less common [70].

Clinical studies have documented the accumulation of metal ion debris and increased inflammation in paraspinal tissues at the level of spinal arthrodesis as well as inside macrophages in areas near the pedicle screw-rod junction [71]. Macrophage activation initiated by metal ion debris may lead to increased inflammation and bone resorption resulting in eventual loosening of the implant $[38,39,68,69,71]$. In addition to local tissue responses metal ions may disseminate into the blood stream and remote organs, of which the long-term consequences are unknown [53].

In recent decades, attention in the literature has been drawn to metal hypersensitivity as another possible cause of implant failure. Although, there has been increasing interest in the field of artificial disc replacement to treat cervical degenerative disc disease, not much has been mentioned in the literature about the potential complications of the disc itself. Spinal implants have been only rarely implicated in case or group studies of hypersensitivity [72]. Implant-related metal sensitivity is well documented in case and group studies, though overall it remains a relatively unpredictable and poorly-understood phenomenon. The Authors reported secondary recurrence of C5-C6 radiculalgia following implantation of a cervical chromium-cobalt-molybdenum prosthesis. Imaging found a prevertebral mass and necrotic tissue. Histology found a hyaline membrane and numerous lymphocytes, but not metal debris.

Zairi et al. [73] reported a case of delayed hypersensitivity following L5-S1 chromium-cobalt-molybdenum metal-onmetal total disc replacement (Maverick). Two months postoperatively, the patient developed progressive lumbar radiculalgia and, at 3 months, cauda equina syndrome, urinary incontinence and iliac vein thrombosis. Imaging found an intracanal mass, accounting for the symptomatology. Patch tests for chromium and $1 \%$ cobalt chloride were positive.

Shang et al. [74] reported a slight swelling of the scar, sensitive to the touch, without associated rash. However, despite the various cases of hypersensitivity reported in the literature, cutaneous signs are rare. Aseptic loosening of the hardware and an aseptic inflammatory response was diagnosed to be metal hypersensitivity. Lagier et al. [75] reported a case of allergic reaction after total cervical disc arthroplasty; rash occurring remote from the surgical scar after cervical disc replacement. Allergy tests confirmed type-4 allergic reaction to chromium.

Berry et al. [76] reported a case of onset of iliac vein and vena cava thrombosis associated with cauda equina syndrome following Maverick total L4-L5 disc replacement. At 1 year postoperatively, symptomatology associated lower-limb pain, edema and lower-limb weakness. CT found a retroperitoneal mass and obstruction of the left iliac vein and adjacent peridural space. Histology found granuloma and diffuse metallic particles.

Guyer et al. [77] reported 4 cases of pseudotumor following implantation of 1 cervical and 3 lumbar chromium-cobaltmolybdenum prostheses. In each case, after an initially satisfactory result, there was recurrence of progressive pain associated with neurologic deficit. Histology found an avascular hyaline membrane, lymphocytes, macrophages and eosinophil polynucleated cells, suggesting allergic rather than infectious etiology.

One of the major difficulties in understanding the clinical implications of hypersensitivity to the implant components is the lack of universally accepted testing methods. Testing for delayed-type hypersensitivity has been conducted in vivo by skin testing (i.e. so-called patch testing or intradermal testing) and in vitro by lymphocyte transformation testing (LTT) $[5,71]$. Patch testing is still the most widely used method for determining potential metal hypersensitivity reactions prior to the implant procedure or implant failure; however, over the long term, patch testing alone may be and inadequate detector of delayed-type hypersensitivity. While patch testing and metal-LTT testing generally yield the same results, LTT testing may be equally or better suited for the testing of implant related sensitivity, because there is no risk of inducing metal sensitization using skin exposure; metal-LTT is highly quantitative.

Despite the association of implant debris release from implants with adverse immunologic response, cause and effect have not been established in symptomatic patients with spine implants. Specific types of implants with a greater 
propensity to release metal in vivo may be more prone to induce metal sensitivity. The importance of this line of investigation is growing, as the use of metallic spinal implants is increasing and as expectations of implant durability and performance increase [71].

Spinal implants are made from a variety of materials to meet the unique mechanical demands of each application. However, the medical device community has raised concern about mixing dissimilar metals in an implant because of fear of inducing corrosion that could potentially compromise the implants and lead to aceptic loosening, implant failure, or adverse biological reaction in host tissue.

Hybrid spinal implants that combine cobalt-chromium (CoCrMo) rods and screw heads with titanium (Ti) screws have recently gained popularity owing to enhanced biomechanical properties and superior deformity correction [78-80]. However, there are resent concerns raised due to corrosion and wear [3,27] and tissue reactions such as metallosis $[23,27,39]$. There are more recent suggestions that the physical and mechanical properties of $\mathrm{CoCr}$ rods are more appropriate for the increased correctional forces of the deformed spine than rods made of different material [78]. Using two different metals (cobalt-chromium and titanium alloys) can induce galvanic and fretting corrosion which may augment release of metal ions $[81,82]$. In the case of instrumentation that uses dissimilar methods, only preclinical testing has been performed [82] and neither post marker surveillance studies using blood metal ions, nor implant retrieval studies. Panagiotopoulou et al. [18] described corrosion scores for the assessment of retrieval spinal implants with two types of material combinations: similar (Ti/Ti) and dissimilar ( $\mathrm{CoCr} / \mathrm{Ti})$. Using this score, Authors found no evidence of increased corrosion when two different materials are galvanically coupled in spine instrumentation. This suggest that metallosis may due more than just implant risk factors.

Given the increasing popularity of hybrid $\mathrm{CoCr}$ and Ti spinal implants, large-scale studies are needed to evaluate whether these implants increase the risk of implant loosening and to clarify the unforeseen dangers of metals ion concentrations and their clinical relevance after spine surgery using combinations of dissimilar metal constructs in order to guide the surgeon in choosing implants.

Radiographic evidence of corrosion, implant failure, pseudarthrosis, revision surgery and adverse reaction reporting was highly variable. Our review revealed conflicting results with some studies showing a relationship between elevated metal ion levels and radiographic evidence of corrosion or implant failure whereas others found no association. Unlike the reports from Takahashi et al. [7], and Tezer et al. [8] where intraoperative evidence of titanium metalwork corrosion or loosening were seen in plain radiographies, while in other case there has been no noted intraoperative or radiological evidence of loosening or corrosion [6,32]. In clinical practice, evaluation of radiographic and blood test results can serve as indication of corrosion and wear in spine implants, although they are not established as part of the routine monitoring of patients. Radiographs and metal levels may help guide diagnosis; however, surgical exploration is needed for early, definitive diagnosis of corrosion and treatment. However, it is possible that for different kinds of spinal instrumentations in which corrosion has been reported in the literature, metal levels can be more useful than looking for radiographic signs of corrosion.

Clinical specimen samples serve as a final example to illustrate the diversity of applications in which multi-elemental analyses at trace levels play a key role. To evaluate potential negative health effects from metals releases from spinal implants, accurate determination of many metals at sub- $\mu \mathrm{g}$ L-1 levels in bodily fluid specimens is necessary. Specimen metal ion measurement must be performed under the rules of internal/external quality control and using a validated method [5].

Several analytical alternatives have been proposed in the literature for the determination of metals in clinical specimens. However, it is important to mention that the accuracy of analytical methods was only properly evaluated in a few studies [39,43,57]. As there are several types of specimens used for the determination of metals, the most suitable tool determination of metals should always be selected according to the specimen collection procedure, the analytical method, the characterization of the metals and the complexity of the specimen matrix (whole blood, serum, plasma, or urine).

Elevated concentrations of trace metals (Al, Co, Cr, Ni, Mo, and Ti) have been reported in the whole blood of patients with failed metallic spinal implants [28,38], in plasma [52] and serum [10,22,23,37,39-51,53-55,57-61,63-66], urine $[23,55]$, and in soft tissue $[9,27,28,30,31]$. Several studies reported in the literature describe the determination of metals in patients with spinal implants by spectrometric techniques, among them inductively coupled plasma mass spectrometry (ICP-MS) $[9,22,28,37-49,61,63,64,66]$, and inductively coupled plasma optical emission spectrometry (ICP-OES) $[9,30,39,47]$. Graphite furnace atomic absorption spectrometry (GF-AAS) has also used for the determination 
of metals in patients with spinal implants [27,31,51,53-55,57-60]. However, several studies did not clarify what technique was used $[10,23,50,52,65]$.

Metal ion measurements, prevalently cobalt, chromium, nickel, and titanium, in blood or serum allow the early detection of increased wear metal debris before extensive tissue destruction has occurred with a better outcome of revisions. Unfortunately, there is growing evidence that grossly elevated metal ion measurements alone are not sufficient method to detect failing or failed spinal implants, and controversy exists in determining the optimal cut-off levels. Given the large discrepancies between published figures (i.e. detection limits, reference ranges) for local metal levels, it is important to determine approximate threshold values for these trace metals in various biological specimen matrices (samples) to serve an indicator for abnormal metallic wear and/or device failure. Currently there is no known concentration threshold or specific elevated metal ions leading to initial inflammatory local tissue reactions in the body or no cut-off values have been consistently and reliably proposed [23,54], if compared with the best described literature of metal-on-metal hip implanted patients that presented implant failure and local metallosis needing surgical intervention for revision [5]. The potential of released spinal implant debris to induce inflammation and osteolysis in the spine is well accepted, yet it remains unknown how to determine what tolerable thresholds are for each individual.

It may be recommendable to establish basal metal levels in patients with specific kinds of stainless steel, titanium, and cobalt-chromium alloy instrumentations and to perform metal concentration analysis as a part of the periodical clinical evaluation. This may allow an early diagnosis of corrosion, preventing local complications. Also, metal levels may be useful in defining the role of corrosion in late operative site pain and late infection of metallic spinal implants. Monitoring with standardized analysis techniques to allow comparability is needed.

Speciation analysis should also be carried out because the toxic effects of metals depend on the species present in the clinical specimen sample, and this should be considered to establish maximum limits in new official recommendations. Because there are no analytical protocols exist for this purpose, therefore, there is a need to develop methods in this regard.

\section{Conclusion}

Metal implants are routinely used in healthcare but may fail following degradation in the body. The increasing use of metallic spinal implants has stimulated interest and concern regarding the chronic, long-term effects of the metallic materials used. This review focuses on the current knowledge of the adverse local tissue reactions to metal debris, nanoparticles and ions, released from spine arthroplasty implants in vivo. Specifically, the purpose of this article is to provide an overview of the literature about the adverse effects of metal nanoparticles and trace metal ions on surrounding soft tissues and bodily fluids, resulting in instrumentation failure in patients with spine constructs. This review produced useful information regarding the production and distribution of particulate metallic debris around spinal implants. As a consequence, the determination of metal levels in clinical specimen samples has become a priority, and analytical/clinical methodologies have had to improve to meet more demanding expectations for accuracy, precision, analysis times and multi metal assays.

\section{Compliance with ethical standards}

\section{Acknowledgments}

This research did not receive any specific grant from funding agencies in the public, commercial, or not-for-profit sectors.

\section{Disclosure of conflict of interest}

All authors declare no conflicts of interest associated with this manuscript.

\section{References}

[1] Orthopedic Implants. 2017. Spine-Health.

[2] Rajaee SS, Kanim LEA, Bae HW. National trends in revision spinal fusion in the USA: patient characteristics and complications. Bone and Joint Journal. 2014; 96-B(6): 807-16. 
[3] Oladokuna A, Petterssonb M, Bryanta M, Engqvistb H, Perssonb C, Halla R, Nevillea A. The fretting of CoCrMo and Ti6Al4V alloys in modular prostheses. Tribology-Materials, Surfaces and Interfaces. 2015; 9(4): $165-73$.

[4] Heffernan EJ, Alkubaidan FO, Nielsen TO, Munk PL. The imaging appearances of metallosis. Skeletal Radiology. 2008; 37(1): 59-62.

[5] Matusiewicz H, Richter M, Potentially toxic metallic wear nanoparticles and trace metal ions release from metalon-metal orthopedic implants in the human biological specimens: An Overview of in vivo and ex vivo clinical studies. World Journal of Advanced Research and Reviews. 2020; 8(3): 242-292.

[6] Goldenberg Y, Tee JW, Salinas-La Rosa CM, Murphy M. Spinal metallosis: a systematic review. European Spine Journal. 2016; 25: 1467-73.

[7] Takahashi S, Delécrin J, Passuti N. Intraspinal metallosis causing delayed neurologic symptoms after spinal instrumentation surgery. Spine. 2001; 26(13): 1495-8.

[8] Tezer M, Kuzgun U, Hamzaoglu A, Ozturk C, Kabukcuoglu F. Sirvanci, Intraspinal metalloma resulting in late paraparesis. Archives of Orthopaedic and Trauma Surgery. 2005; 125(6): 417-21.

[9] Ayers R, Miller M, Schowinsky J, Burger E, Patel V, Kleck C. Three cases of metallosis associated with spine instrumentation. Journal of Material Science: Materials in Medicine. 2018; 29: 1-9.

[10] Richman SH, Razzano AJ, Morscher MA, Riley Sr PM. Metallosis presenting as a progressive neurologic deficit four years after a posterior spinal fusion for adolescent idiopathic scoliosis: A case report. Spine. 2017; 42(1): E56E9.

[11] Teoh KH, von Ruhland C, Evans SL, James SH, Jones A, Howes J, Davies PR, Ahuja S. Metallosis following implantation of magnetically controlled growing rods in the treatment of scoliosis. Bone and Joint Journal. 2016; 98-B: 1662-7.

[12] Tahal D, Madhavan K, Onn Chieng L, Ghobrial GM, Wang MY. Metals in spine. World Neurosurgery. 2017; 100: 619-27.

[13] Warburton A, Girdler SJ, Mikhail CM, Ahn A, Cho SK, Biomaterials in spinal implants: A Review. Neurospine. 2020; 17(1): 101-10.

[14] Botolin S, Merritt C, Erickson M. Aseptic loosening of pedicle screw as a result of metal wear debris in a pediatric patient. Spine. 2013; 38(1): E38-E42.

[15] Gaine WJ, Andrew SM, Chadwick P, Cooke E, Williamson JB, Late operative site pain with isola posterior instrumentation requiring implant removal: infection or metal reaction? Spine. 2001; 26(5): 583-7.

[16] Kirkpatrick JS, Venugopalan R, Beck P, Lemons J. Corrosion on spinal implants. Journal of Spinal Disorders and Techniques. 2005; 18(3): 247-251.

[17] Villarraga ML, Cripton PA, Teti SD, Steffey DL, Krisnamuthy S, Albert T, Hilibrand A, Vaccaro A. Wear and corrosion in retrieved thoracolumbar posterior internal fixation. Spine. 2006; 31(21): 2454-62.

[18] Panagiotopoulou VC, Hothi HS, Anwar HA, Molloy S, Noordeen H, Rezajooi K, Sutcliffe J, Skinner JA, Hart AJ. Assessment of corrosion in retrieved spine implants. Journal of Biomedical Materials Research Part B: Applied Biomaterials. 2018; 106B: 632-8.

[19] Aulisa L, di Benedetto A, Vinciguerra A, Lorini G, Tranquilli-Leali P. Corrosion of the Harrington's instrumentation and biological behaviour of the rod-human spine system. Biomaterials. 1982; 3(4): 246-8.

[20] Akazawa T, Minami S, Takahashi K, Kotani T, Hanawa T, Moriya H. Corrosion of spinal implants retrieved from patients with scoliosis. Journal of Orthopaedic Science. 2005; 10(2): 200-5.

[21] Vieweg U, Van Roost D, Wolf HK, Schyma CA, Schramm J. Corrosion on an internal spinal fixator system. Spine. 1999; 24(10): 946-51.

[22] Kim Y-J, Kassab F, Berven SH, Zurakowski D, Hresko MT, Emans JB, Kasser JR. Serum levels of nickel and chromium after instrumented posterior spinal arthrodesis. Spine. 2005; 30(8): 923-6.

[23] Del Rio J, Beguiristain J, Duart J. Metal levels in corrosion of spinal implants. European Spine Journal. 2007; 16: 1055-61. 
[24] Denaro V, Papapietro N, Sgambato A, Barnaba SA, Ruzzini L, Paola B, Rettino A, Cittadini A. Periprosthetic electrochemical corrosion of titanium and titanium-based alloys as a cause of spinal fusion failure. Spine. 2008; 33(1): 8-13.

[25] Jacobs JJ, Hallab NJ, Skipor AK, Urban RM. Metal degradation products. A cause for concern in metal-metal bearings? Clinical Orthopaedics and Related Research. 2003; 417: 139-47.

[26] Affatato S (Ed.), Wear of orthopaedic implants and artificial joints, Woodhead Publishing, USA. 2012.

[27] Wang JC, Yu WD, Sandhu HS, Betts F, Bhuta S, Delamarter RB. Metal debris from titanium spinal implants. Spine. 1999; 24(9): 899-903.

[28] Lukina E, Laka A, Kollerov M, Sampiev M, Mason P, Wagstaff P, Noordeen H, Yoon WW, Blunn G. Metal concentrations in the blood and tissues after implantation of titanium growth guidance sliding instrumentation. Spine Journal. 2016; 16: 380-8.

[29] Senaran H, Atilla P, Kaymaz F, Acaroglu E, Surat A. Ultrastructural analysis of metallic debris and tissue reaction around spinal implants in patients with late operative site pain. Spine. 2004; 29(15): 1618-23.

[30] Krischak GD, Gebhard F, Mohr W, Krivan V, Ignatius A, Beck A, Wachter NJ, Reuter P, Arand M, Kinzl L, Claes LE. Difference in metallic wear distribution released from commercially pure titanium compared with stainless steel plates. Archives of Orthopaedic and Trauma Surgery. 2004; 124: 104-13.

[31] Golasik M, Herman M, Jasiewicz B, Tęsiorowski M, Piekoszewski W. Development of a method for the determination of titanium in tissue by graphite furnace atomic absorption spectrometry for clinical analysis. Journal of Analytical Atomic Spectrometry. 2014; 29: 1844-9.

[32] Siddiqi O, Urquhart JC, Rasoulinejad P. A systematic review of metal ion concentrations following instrumented spinal fusion. Spine Deformity. 2021; 9(1): 13-40.

[33] Swiatkowska I, Martin N, Hart AJ. Blood titanium level as a biomarker of orthopaedic implant wear. Journal of Trace Elements in Medicine and Biology. 2019; 53: 120-8.

[34] Koller D, Bramhall P, Devoy J, Goenaga-Infante H, Harrington CF, Leese E, Morton J, Nuñez S, Rogers J, Sampson B, Powell JJ. Analysis of soluble or titanium dioxide derived titanium levels in human whole blood: consensus from an inter-laboratory comparison. Analyst. 2018; 143: 5520-9.

[35] Golasik M, Herman M, Piekoszewski W. Toxicological aspects of soluble titanium - a review of in vitro and in vivo studies. Metallomics. 2016; 8: 1227-42.

[36] Chan EPH, Mhawi A, Clode P, Saunders M, Filgueira L. Effects of titanium(IV) ions on human monocyte-derived dendritic cells. Metallomics. 2009; 1: 166-74.

[37] Richardson TD, Pineda SJ, Strenge KB, Van Fleet TA, MacGregor M, Milbrandt JC, Espinosa JA, Freitag P. Serum titanium levels after instrumented spinal arthrodesis. Spine. 2008; 33(7): 792-6.

[38] Ipach I, Schäfer R, Mittag F, Leichtle C, Wolf P, Kluba T. The development of whole blood titanium levels after instrumented spinal fusion - Is there a correlation between the number of fused segments and titanium levels? BMC Musculoskeletal Disorders. 2012; 13: 159.

[39] Kasai Y, Iida R, Uchida A. Metal concentrations in the serum and hair of patients with titanium alloy spinal implants. Spine. 2003; 28(12): 1320-6.

[40] Cundy TP, Antoniou G, Sutherland LM, Freeman BJC, Cundy PJ. Serum titanium, niobium, and aluminum levels after instrumented spinal arthrodesis in children. Spine. 2013; 38(7): 564-70.

[41] Cundy TP, Cundy WJ, Antoniou G, Sutherland LM, Freeman BJC, Cundy PJ. Serum titanium, niobium and aluminium levels two years following instrumented spinal fusion in children: does implant surface area predict serum metal ion levels? European Spine Journal. 2014; 23: 2393-400.

[42] Cundy WJ, Mascarenhas AR, Antoniou G, Freeman BJC, Cundy PJ. Local and systemic metal ion release occurs intraoperatively during correction and instrumented spinal fusion for scoliosis. Journal of Children's Orthopaedics. 2015; 9: 39-43.

[43] Yilgor C, Efendiyev A, Akbiyik F, Demirkiran G, Senkoylu A, Alanay A, Yazici M. Metal ion release during growthfriendly instrumentation for early-onset scoliosis: A Preliminary study. Spine Deformity. 2018; 6: 48-53. 
[44] Danielewicz A, Fatyga M, Wójciak-Kosior M, Sawicki J, Różańska-Boczula M, Sowa I, Latalski M. The mechanical aspect of titanium ion release after posterior instrumentation for early onset scoliosis. Physicochemical Problems of Mineral Processing. 2019; 55(6): 1442-9.

[45] Bances IF, Aparicio JP, Vega MAA. Evaluation of titanium serum levels in patients after spine instrumentation: Comparison between posterolateral and 360o spinal fusion surgery. Cureus. 2019; 11(8): e5451.

[46] Nuevo-Ordóñez Y, Montes-Bayón M, Blanco-González E, Paz-Aparicio J, Raimundez JD, Tejerina JM, Peña MA, Sanz-Medel A. Titanium release in serum of patients with different bone fixation implants and its interaction with serum biomolecules at physiological levels. Analytical and Bioanalytical Chemistry. 2011; 401(9): $2747-54$.

[47] Patton MS, Lyon TDP, Ashcroft GP. Levels of systemic metal ions in patients with intramedullary nails. Acta Orthopaedica. 2008; 79(6): 820-5.

[48] McGarry S, Morgan SJ, Grosskreuz RM, Williams AE, Smith WR. Serum titanium levels in individuals undergoing intramedullary femoral nailing with a titanium implant. Journal of Trauma: Injury, Infection, and Critical Care. 2008; 64(2): 430-3.

[49] Gornet MF, Singh V, Schranck FW, Skipor AK, Jacobs JJ. Serum metal concentrations in patients with titanium ceramic composite cervical disc replacements. Spine. 2017; 42(6): 366-71.

[50] Brembilla C, Giampreti A, Lanterna LA, Bacis G, Gritti P, Locatelli CA, Trezzi R, Bernucci C. Metal release from spinal arthrodesis: implant failure and local metal release but only slightly elevated serum levels. Journal of Neurosurgical Sciences. 2019; 63(4): 481-4.

[51] Rackham MD, Cundy TP, Antoniou G, Freeman BJC, Sutherland LM, Cundy PJ. Predictors of serum chromium levels after stainless steel posterior spinal instrumentation for adolescent idiopathic scoliosis. Spine. 2010; 35(9): 975-82.

[52] Sherman B, Crowell T. Corrosion of Harrington rod in idiopathic scoliosis: long-term effects. European Spine Journal. 2018; 27(Suppl 3): 298-302.

[53] Cundy TP, Delaney CL, Rackham MD, Antoniou G, Oakley AP, Freeman BJC, Sutherland LM, Cundy PJ. Chromium ion release from stainless steel pediatric scoliosis instrumentation. Spine. 2010; 35(9): 967-74.

[54] Savarino L, Greggi T, Martikos K, Lolli F, Greco M, Baldini N. Long-term systemic metal distribution in patients with stainless steel spinal instrumentation. Journal of Spinal Disorders and Techniques. 2015; 28(3): 114-8.

[55] McPhee IB, Swanson CE. Metal ion levels in patients with stainless steel spinal instrumentation. Spine. 2007; 32(18): 1963-8.

[56] Jones DM, Marsh JL, Nepola JV, Jacobs JJ, Skipor AK, Urban RM, Gilbert JL, Buckwalter JA, Focal osteolysis at the junctions of a modular stainless-steel femoral intramedullary nail. Journal of Bone and Joint Surgery Am. 2001; 83(4): 537-48.

[57] Savarino L, Maci GS, Greco M, Baldini N, Giunti A. Metal ion release from fracture fixation devices: A Potential marker of implant failure. Journal of Biomedical Materials Research Part B: Applied Biomaterials. 2008; 86(2): 389-95.

[58] Savarino L, Stea S, Granchi D, Visentin M, Ciapetti G, Donati ME, Rollo G, Zinghi G, Pizzoferrato A, Montanaro L, Toni A. Sister chromatid exchanges and ion release in patients wearing fracture fixation devices. Journal of Biomedical Materials Research. 2000; 50(1): 21-6.

[59] Zeh A, Planert M, Siegert G, Lattke P, Held A, Hein W. Release of cobalt and chromium ions into the serum following implantation of the metal-on-metal Maverick-type artificial lumbar disc (Medtronic Sofamor Danek). Spine. 2007; 32(3): 348-52.

[60] Zeh A, Becker C, Planert M, Lattke P, Wohlrab D. Time-dependent release of cobalt and chromium ions into the serum following implantation of the metal-on-metal Maverick type artificial lumbar disc (Medtronic Sofamor Danek). Archives of Orthopaedic and Trauma Surgery. 2009; 129(6): 741-6.

[61] Skipor AK, Harper ML, Gornet MF, Burkus JK, Chan FW, Jacobs JJ. Serum metal levels in a metal-on-metal lumbar disc arthroplasty. Trans ORS. 2009; 23: 1847.

[62] Bisseling P, Zeilstra DJ, Hol AM, van Susante JLC. Metal ion levels in patients with a lumbar metal-on-metal total disc replacement: should we be concerned? Journal of Bone and Joint Surgery Br. 2011; 93(7): 949-54. 
[63] Gornet MF, Burkus JK, Harper ML, Chan FW, Skipor AK, Jacobs JJ. Prospective study on serum metal levels in patients with metal-on-metal lumbar disc arthroplasty. European Spine Journal. 2013; 22: 741-6.

[64] Singh V, Skipor AK, Selim AA, Jacobs JJ. Chromium and nickel concentrations in subjects with a stainless steel metal-on-metal cervical disc arthroplasty: Results from a prospective longitudinal study with 7 years follow-up. International Journal of Spine Surgery. 2018; 12(4): 460-8.

[65] Cheung JPY, Samartzis D, Yeung K, To M, Luk KDK, Cheung KMC. A randomized double-blinded clinical trial to evaluate the safety and efficacy of a novel superelastic nickel-titanium spinal rod in adolescent idiopathic scoliosis: 5-year follow-up. European Spine Journal. 2018; 27(2): 327-9.

[66] Cundy TP, Kirby CP. Serum metal levels after minimally invasive repair of pectus excavatum. Journal of Pediatric Surgery. 2012; 47: 1506-11.

[67] Mody DR, Esses SI, Heggeness MH. A histologic study of soft-tissue reactions to spinal implants. Spine. 1994; 19(10): 1153-6.

[68] Cook S, Asher M, Lai S-M, Shobe J. Reoperation after primary posterior instrumentation and fusion for idiopathic scoliosis. Toward defining late operative site pain of unknown cause. Spine 200; 25(4): 463-8.

[69] Hallab NJ, Cunningham BW, Jacobs JJ. Spinal implant debris-induced osteolysis. Spine. 2003; 28(20S): S125-S38.

[70] Cohen J, Lindenbaum B. Fretting corrosion in orthopedic implants. Clinical Orthopaedics and Related Research. 1968; 61: 167-75.

[71] Hallab NJ. A review of the biologic effects of spine implant debris: Fact from fiction. SAS Journal. 2009; 3: 143-60.

[72] Cavanaugh DA, Nunley PD, Kerr EJ, Werner DJ, Jawahar A. Delayed hyper-reactivity to metal ions after cervical disc arthroplasty. Spine. 2009; 34(7): E262-E5.

[73] Zairi F, Remacle JM, Allaoui M, Assaker R. Delayed hypersensitivity reaction caused by metal-on-metal total disc replacement. Case report. Journal of Neurosurgery: Spine. 2013; 19(3): 389-91.

[74] Shang X, Wang L, Kou D, Jia X, Yang X, Zhang M, Tang Y, Wang P, Wang S, Xu Y, Wang H. Metal hypersensitivity in patient with posterior lumbar spine fusion: a case report and its literature review. BMC Musculoskeletal Disorders. 2014; 15: 314.

[75] Lagier M, Briere M, Giorgi H, Fuentes S, Blondel B, Tropiano P. Delayed hypersensitivity reactions after cervical disc replacement: A case report. Orthopaedics and Traumatology: Surgery and Research. 2015; 101(5): 643-5.

[76] Berry MR, Peterson BG, Alander DH. A granulomatous mass surrounding a maverick total disc replacement causing iliac vein occlusion and spinal stenosis. A case report. Journal of Bone and Joint Surgery. 2010; 92(5): 1242-5.

[77] Guyer RD, Shellock J, MacLennan B, Hanscom D, Knight RQ, McCombe P, Jacobs JJ, Urban RM, Bradford D, Ohnmeiss DD. Early failure of metal-on-metal artificial disc prostheses associated with lymphocytic reaction: diagnosis and treatment experience in four cases. Spine. 2011; 36(7): E492-E7.

[78] Serhan H, Mhatre D, Newton P, Giorgio P, Sturm P. Would CoCr rods provide better correctional forces than stainless steel or titanium for rigid scoliosis curves? Journal of Spinal Disorders and Techniques. 2013; 26(2): E70-E4.

[79] Lamerain M, Bachy M, Delpont M, Kabbaj R, Mary P, Vialle R. CoCr rods provide better frontal correction of adolescent idiopathic scoliosis treated by all-pedicle screw fixation. European Spine Journal. 2014; 23(6): 11906.

[80] Shah KN, Walker G, Koruprolu SC, Daniels AH. Biomechanical comparison between titanium and cobalt chromium rods used in a pedicle subtraction osteotomy model. Orthopaedics Reviews (Pavia). 2018; 10(1): 7541.

[81] Zartman KC, Berlet GC, Hyer CF. Combining dissimilar metals in orthopaedic implants: Revisited. Foot and Ankle Specialist. 2011; 4(5): 318-23.

[82] Mali SA, Singh V, Gilbert JL. Effect of mixed alloy combinations on fretting corrosion performance of spinal screw and rod implants. Journal of Biomedical Materials Research Part B: Applied Biomaterials. 2017; 105(5): 116977. 